DOI: $10.22363 / 2312-9182-2019-23-1-62-82$

\title{
How Not To Do Things with the Word: Barack Obama on the Armenian Genocide ${ }^{1}$
}

\author{
Suren Zolyan \\ Immanuel Kant Baltic Federal University \\ 14 A. Nevskogo St., Kaliningrad, 236041, Russia \\ 44 Arami St., Yerevan, 375010, Armenia
}

Institute of Philosophy, Sociology and Law, National Academy of Sciences of Armenia

\begin{abstract}
The overarching premise of the paper is the idea that Barack Obama's discursive strategies used in connection with the Armenian genocide in the annual commemoratory Statements could be considered "evasionist" because of the omission of the term 'genocide' and its substitution with the semi-official neologism of 'Meds Yeghern', transliteration of the Armenian name of the 1915 genocide. Such evasionist discourse in presidential statements avoids unambiguous assessments and expressions, thereby catering to recipients with different political attitudes and expectations. By analyzing different connotative and meta-linguistic mechanisms of taboo in modern political discourse, we show how Obama radically transforms the semantic principles of his predecessors' discourse, maintaining identical goal-setting characteristics. It is argued that the transliteration of the Armenian name of the genocide can mean "everything and nothing" - for the Armenian audience, it implies full validation of their viewpoint and language, while for the rest of the world, it is only a meaningless sign. The paper demonstrates that the linguistic and semiotic resources that make up Barack Obama's discourse on the Armenian genocide are based on intentional ambiguity and ambivalent interpretational strategies where intertextual linkages replace referential semantics. A hermeneutic approach appears to be the most adequate instrument for interpretation of such types of discourse, i.e. an interpreter is authorized to explicate inter-textual meanings and messages, which are implicitly incorporated within the text.
\end{abstract}

Keywords: Political discourse, Obama, the Armenian Genocide, taboo, Meds Yeghern, intertextuality

\section{Как не действовать словом: Барак Обама о геноциде армян 1915 г.}

\author{
С.Т. Золян
}

Балтийский федеральный университет им. И. Канта

Россия, 236041, Калининград, 14 А. ул. Невского,

Институт философии, социологии и права Национальной академии наук Армении Армения, 375010, Ереван, 44 ул. Арами

В основе статьи - описание дискурсивных стратегий Барака Обамы при его обращении к теме геноцида армян 1915 года. Этот тип дискурса, как и официальный американский дискурс на эту тему в целом, можно охарактеризовать как «уклонистский». Сам термин «геноцид» заменяется полуофициальным неологизмом «Медс Егерн», транслитерацией армянского наименования геноцида 1915 г. Подобный дискурс уклоняется от однозначных оценок и выражений, в связи с чем, в отличие от утверждающих или отрицающих, оказывается приемлемым для адресатов с различными политическими установками и ожиданиями. Анализируя различные коннотативные и металинг-

${ }^{1}$ The research is supported by the Russian Science Foundation, project № 18-18-00442 "Mechanisms of meaning production and textualization in social narrative and performative discourses and practices", at the Im. Kant Baltic Federal University, Kaliningrad, Russia. 
вистические механизмы табуирования, мы показываем, как Обама радикально трансформирует семантические принципы дискурса своих предшественников и вместе с тем сохраняет те же целеполагающие характеристики. Транслитерированное армянское наименование геноцида 1915 г. может означать «все и ничего»: для армянской аудитории это означает полное принятие их точки зрения и языка, в то время как для остального мира это только непонятный знак. Демонстрируется, что лингвистические и семиотические ресурсы дискурса Барака Обамы о геноциде армян основаны на преднамеренной двусмысленности и амбивалентных интерпретационных стратегиях, где межтекстовые связи заменяют референтную семантику. Герменевтический подход представляется наиболее адекватным инструментом для интерпретации подобных типов дискурса, когда интерпретатор наделяется компетенцией эксплицировать те интертекстуальные смыслы и сообщения, которые имплицитно содержатся в тексте.

Ключевые слова: политический дискурс, табуирование, Обама, геноиид армян, Медс Егерн, интертекстуальность

I forgot the word I wished to say...

And the fleshless thought returns to the chamber of shadows. Osip Mandelstam

\section{INTRODUCTION}

It is widely recognized that now a significant change has occurred in the principles of political discourse construction. Some aspects of this change can be identified by examining the discursive practices in Barack Obama's references to the Armenian genocide in comparison with the similar discourse of his predecessors. We intend to consider this subject as a semiotic, rather than a political or legal issue: how one is able not to use the word 'genocide', yet at the same time refer to its meaning - a case that demonstrates how the old practice of taboo meets the current intertextual and contextual techniques of post-modernist writing. The proposed analysis reveals new linguistic and semiotic mechanisms which are more common in poetic discourse and seem to replace devices of traditional rhetoric of political discourse in general, and taboo, in particular. The linguistic and semiotic resources that make up Barack Obama's discourse on the Armenian genocide are based on intentional ambiguity and ambivalent interpretational strategies where intertextual linkages replace referential semantics. However, as we shall demonstrate in the paper, Obama radically transforms the semantic principles of his predecessors' discourse, yet maintains its political goal-setting characteristics, fabricating what is here termed as a "maneuvering" or "evasionist" discourse. Such discourses, represented by the Statements of the American presidents on the events of 1915, avoid unambiguous assessments and expressions and therefore can be acceptable to recipients with different political attitudes and expectations.

On 24 April, 1994, Bill Clinton made the American presidential commemoratory addresses to the Armenian people an annual tradition, thereby establishing the special textual pattern of the presidential addresses to be subsequently inherited by George Bush. The semantics of this discourse on the one hand suggests political loyalty to the previous US approach to the 1915 events, while on the other hand it is determined by foreign policy implications with regard to the usage of the term 'genocide'.

In what follows, we consider the changes Barrack Obama introduced to the already settled canon. Obama's situation was more complicated: as a presidential candidate, he 
promised that if elected he would recognize the Armenian genocide. Instead, when already a US president, Obama creates an ambiguous text, in which the unexplained expression 'Meds Yeghern' (the transliteration of the Armenian name of the 1915 Genocide) means "everything and nothing". For the Armenian audience, this indicates a full acceptance of their point of view and even their language, but for the rest of the world, it is only a meaningless sign. In the fifth part of this paper, we trace how the word entered English, becoming the quasi-official euphemistic designation of the events of 1915, now used even by Obama's most fervent rival, Donald Trump. In the sixth part, we examine the intertextual mechanisms of non-naming the word "genocide" through reference to texts where this term is explicitly expressed - a novelty for political discourse but quite common for twentieth-century poetic practices. This technique allows Obama both to confirm his previous position and preserve the principle of "non-naming" the tabooed expression, as his predecessors did it.

The conclusion summarizes the set of possible principles of interpretation pertinent to the so-called evasionist discourse. We conclude that the methods of hermeneutical analysis can be applied to substitute the accepted procedures of verification and falsification. In contrast to the traditional unanimous rhetoric of Clinton, Obama's postmodernist discourse ${ }^{2}$ is based on implied meanings and ambiguity, delegating the interpreter to reconstruct allusions and explicate inter-textual meanings and messages, implicitly incorporated within the text.

\section{AMERICAN PRESIDENTS ON THE ARMENIAN GENOCIDE}

To correctly evaluate the linguistic features of the texts under consideration, it is necessary to escalate their political goals. The visible and compact corpus of statements by American presidents makes it possible to identify linguistic and semiotic mechanisms to express and implement these political objectives.

It is a commonly accepted practice that discourses related to genocide are of two types:

a. Recognizing discourses; or b. Denialist discourses, denying either the very facts of the crimes or the legitimacy of the use of the term 'genocide'. However, it seems that the third type of discourses has to be introduced: discourses that are "maneuvering" or "evasionist" (Zolyan 2015). In such discourse the events are described through ambivalent linguistic expressions which can be subjected to quite different interpreta-

${ }^{2}$ Cf. with the characteristics given by some of Obama's conservative opponents: "Barack Obama has earned his place in history as the first postmodern candidate for president. He belongs to the deconstructionist school; his "texts" have no fixed meaning. He is able to take varying positions and claim consistency... It appears that everything he says and does must be viewed "in context" and that the framing of that context is the sole province of Barack Obama". David Bueche. Obama the Postmodern Candidate // AmericanThinker July 27, 2008 (http://www.americanthinker.com/articles/ 2008/07/obama_the_postmodern_candidate.html) (accessed 06.12.2018) Or: "President Obama spent his formative years in academia, so he's no doubt familiar with postmodernism, the literary theory that rejects objective reality and insists instead that everything is a matter of interpretation and relative "truth". The Postmodern President // The Wall Street Journal. 09.08.2012 (http://www.wsj.com/articles/ SB10000872396390443537404577577193632921170) (accessed 06.12.2018). 
tions, catering to the expectations of various recipients. Such discourse does not deny anything, but at the same time, it asserts nothing. The main objective, nevertheless, is to evade the recognition of the genocide without denying it. Therefore, the main communicative purpose of such discourse is paying tribute to the genocide victims but without uttering the tabooed word. This case is more than the conventional political correctness; it can be considered as a peculiar manifestation of taboo in modern ritualized political communication. "The power of word", "The magic of word", etc. are common expressions for comments on the usage or non-usage of the word 'genocide'. While the main attention is usually concentrated on political objectives, the lexical and textual aspects of "evasionism" are not considered. The compact corpus of the Statements of American presidents makes it possible to see through which linguistic and semiotic mechanisms these political goals are supposed to be achieved.

Since the very beginning of the 1915 events, the American government and society were aware of what was happening in the Ottoman Empire at that time. The memos and cables of American diplomats and missionaries are among the most important documents about the crimes committed by the Turkish government. They confirmed the existence of state-orchestrated actions for the complete extermination of the Armenian population ${ }^{3}$. It is a well-known fact that President Woodrow Wilson and the Congress of the United States condemned those crimes and demanded compensation for the victims and punishment for the organizers. However, Woodrow Wilson and the Congress characterized the events as "mass atrocities" (Wilson, 1920). Certainly, the word 'genocide' cannot be articulated - since only three decades later Rafael Lemkin, while characterizing those crimes coined this term and formed the basis of the Convention on the Prevention and Punishment of the Crime of genocide (9 December 1948) .

However, during the Cold War, overshadowed by the foreign policy priorities, the question of the Armenian genocide was never raised officially. This was the case until the 80 s when it was at times addressed by Jimmy Carter, Ronald Reagan, and George H.W. Bush. After the collapse of the Soviet Union, fundamental changes have taken place in the world, among them the re-establishment of the independent Republic of Armenia. Among other factors that helped bring the 1915 events out of oblivion, the strengthening of the Armenian-American community should also be mentioned.

3 As the American ambassador Henry Morgenthau reported in his cable to the government on 16/1915: "Deportation of and excesses against peaceful Armenians is increasing and from harrowing reports of eye witnesses it appears that a campaign of race extermination is in progress under a pretext of reprisal against rebellion" see: http://www.armenian-genocide.org/us-7-16-15-text.html (accessed 06.12.2018). Obama in several occasions used the expression race extermination, as well the Wilsonian definition "the mass atrocities", probably, as intertextual linkages between his reporting and their original statements.

4 This reference is based on Lemkin's autobiographic note: "Soon contemporary examples of genocide followed, such as the slaughter of Armenians in 1915. It became clear to me that the diversity of nations, religious groups and races is essential to civilization because every one of those groups has a mission to fulfil and a contribution to make in terms of culture... I decide to become a lawyer and work for the outlawing of Genocide and for its prevention through the cooperation of nations" (Lemkin 1999: 79). 
It was due to those new political circumstances that since 1994 Bill Clinton made American Presidents Statement on April 24 an annual event named as Armenian Remembrance Day. He also established a particular textual pattern with its vocabulary for such addresses, later inherited by George W. Bush. On the one hand, the semantics of recreating a predecessor's discourse confirms a political continuity and loyalty to the previous US approach to the events of 1915, and on the other hand, the repetition is conditioned by modern foreign policy implications with regard to the term 'genocide" . Instead, descriptive paraphrases are used: mass killings, massacres, crimes against humanity, the great calamity. Of course, this situation is usually explained as a matter of foreign policy: the usage of the word 'genocide' can destroy the relations between USA and Turkey. Expressions like 'massacre' or 'atrocity' do not have definite legal value in international law, so their usage is acceptable. The term 'genocide', conversely, may have some legal consequences. For us, such an explanation sounds rather strange from political and legal points of view: how can the usage of this word cause damage to Turkey? Nothing happened when Ronald Reagan used this word on the occasion of the Commemoration of the victims of the Holocaust ${ }^{6}$, as well as after a series of affirmations of the Armenian genocide by Russia, France, Germany, EU, etc. Avoiding the word 'genocide' may have another explanation. The do-not-anger-Turkey intention and the expected emotional response from the Turkish side are beyond rational policy and international law. Having in mind that the Presidential Statements are not legally binding, this phenomenon can be described rather as a manifestation of the archaic taboo. "Over the years, the debate has come to center on a single word, "genocide", a term that acquired such power that some refuse to utter it aloud, calling it "the Gword", - as this was resumed by the political analyst Thomas de Waal (Waal 2015, p. see also: Gutman, 2015, Cirillo 2016 a, 2016 в).

\section{SENATOR OBAMA ON THE ARMENIAN GENOCIDE}

In comparison with his predecessors, Barack Obama's situation was more complicated from the very beginning of his presidency because, as a senator, on different occasions, he criticized the Republican administration for an evasive approach to

5 This was a general attitude of the Clinton government, and it was also manifested in regard to the events in Rwanda and then in Sudan: "The ban on saying "genocide" by the Clinton administration arose out of a briefing compiled by the Office of the Secretary of Defense. Inside the May 1994 briefing (later declassified by the National Security Archives), State Department lawyers said they were worried that a finding of genocide might obligate the administration "to actually "do something". Rebecca Hamilton. Inside Colin Powell's Decision to Declare Genocide in Darfur // The Atlantic, AUG 17, 2011 — https://www.theatlantic.com/ international/archive/2011/08/inside-colin-powellsdecision-to-declare-genocide-in-darfur/243560/ (accessed 06.12.2018).

6 "Like the genocide of the Armenians before it, and the genocide of the Cambodians which followed it - and like too many other such persecutions of too many other peoples — the lessons of the Holocaust must never be forgotten". Reagan 1981 Proclamation 4838 of April 22, 1981; Days of Remembrance of Victims of the Holocaust (http:www.presidency.ucsb.edu/ws/index.php?pid= 43727\%20) (accessed 06.12.2018). 
the Armenian genocide. First of all, it was an incident with the dismissal of the American ambassador to Armenia, John Evans, in 2006. During his stay in the USA, Ambassador Evans had a semi-official meeting with some representatives of the Armenian Diaspora in California and expressed his opinion:

"I will today call it the Armenian Genocide. I think we, the U.S. government, owe you, our fellow citizens, a more frank and honest way of discussing this problem. The Armenian genocide was the first genocide of the 20th century. I pledge to you. We are going to do a better job at addressing this issue".

Three days later, on 28 Feb, 2005, John Evans released a clarification that he used the term 'genocide' speaking in what he would characterize as personal capacity and deeply regretted any misunderstanding caused by his comments. Despite that, in 2006 the ambassador was recalled without any public explanation. Senator Obama in his letter to State Secretary Condoleezza Rice concerning the firing of John Evans expressed his indignation:

'I believe that the controversy over Ambassador Evans' use of term 'genocide' underscores the fact that the current US position is untenable. That the invocation of a historical fact by a State Department employee could constitute an act of insubordination is deeply troubling. When State Department instructions are such that an ambassador must engage in strain reasoning - or even an outright falsehood - that defies a common sense interpretation of events to follow orders, then it is time to revisit the State Department's policy guidance on this issue ... The occurrence of the Armenian Genocide in 1915 is not an 'allegation', a personal 'opinion' or a 'point of view'. Supported by the overwhelming amount of historical evidence, it is a widely documented fact" $"$.

It is obvious that Obama has concentrated on the semantic aspect of the matter, i.e. on the proper interpretation and nomination of facts. Two years later, as a presidential candidate, Barrack Obama once again referred to this incident, reiterating the same stance:

"Two years ago, I criticized the Secretary of State for the firing of U.S. Ambassador to Armenia, John Evans, after he properly used the term 'genocide' to describe Turkey's slaughter of thousands of Armenians starting in $1915<\ldots>$ An official policy that calls on diplomats to distort the historical facts is an untenable policy"

Instead, Obama promised that if elected for the presidency, he would change such practice of "distortion":

"America deserves a leader who speaks truthfully about the Armenian Genocide and responds forcefully to all genocides. I intend to be that President" ${ }^{\text {"10. }}$.

${ }^{7}$ Emil Danielyan. U.S. Official Affirms Armenian Genocide Friday 25, February 2005. RFE/RL Armenia Report.

${ }^{8}$ https://anca.org/change/docs/Obama_Armenian_Genocide.pdf (accessed 06.12.2018).

9 Barack Obama on the Importance of US-Armenia Relations [Obama' 08 Campaign Statement]: January 19, 2008 (http://www.armenian-genocide.org/Affirmation.413/current_category.4/affirmation detail.html) (accessed 06.12.2018).

10 Ibid. 


\section{PRESIDENT OBAMA DID NOT CHANGE HIS VIEWS, BUT...}

Senator Obama successfully won the elections and, as it was expected, nothing should have prevented him from keeping his promise. However, the strong tradition of taboo was stronger than his previous intentions. The combination of two contradicting premises, the previous statements, and the new political taboo requirements, urged Obama to transform his discourse. Keeping formally in line with the canons established by Clinton, Obama creates an ambiguous postmodernist text: it is addressed to various recipients, and each of them can interpret the text differently following their expectations and by creating multiple intertextual linkages. The identity of the speaker $(\mathrm{I}-\mathrm{we})$ is also ambivalent, referring both to Obama-as-a-person and Obama-as-the-president. In so doing, Obama avoids using unequivocal terms, which are functionally substituted by intertextual references.

Let us recall that the main subject of Obama's letter to the State Secretary was about the proper usage of the term 'genocide': Ambassador Evans was fired as "he properly used the term 'genocide' to describe Turkey's slaughter of thousands of Armenians starting in 1915". Following this logic, one can be punished for the true denotation. However, the semiotics of language can provide another solution, when one can avoid denotation. As Hjelmslev demonstrated it, (1961 (1943)), the denotative semiotics of language (or semiotics of zero degrees) can be substituted by meta-linguistic and connotative semiotics, and the same expression is to be interpreted on different semiotic levels in different ways. Thus, there is a possibility to conceal the denotative plane of expression (primary interpretation) through the chain of connotative or meta-linguistic usages. The common technique of tabooing is based on such replacement of a first interpretation by some of its derivatives. For example, if one tries to avoid uttering the name 'Stalin', one can use other expressions (e.g. 'Uncle Joe', or 'The mustached'). The level of interpretation differentiates these expressions: the name 'Stalin' directly refers to some historical person, Joseph Stalin, while its substitutes refer firstly to his name 'Stalin' and through this name to the person. The tabooed name 'Stalin' is covered under periphrastic expressions, but its meaning can be reconstructed.

Likewise, in Washington-based decision-makers' informal slang, the word 'genocide' was replaced by the 'G-word.' Schematically, this can be represented as a complication of the relationship between the signified and its primary and derivative signifiers. The original denotative interpretation is:

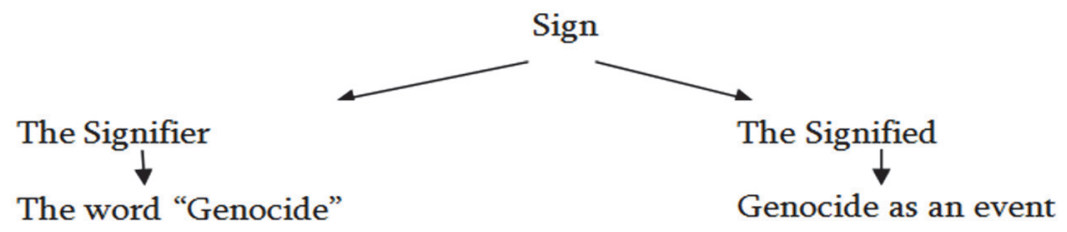

The secondary meta-linguistic interpretation is:

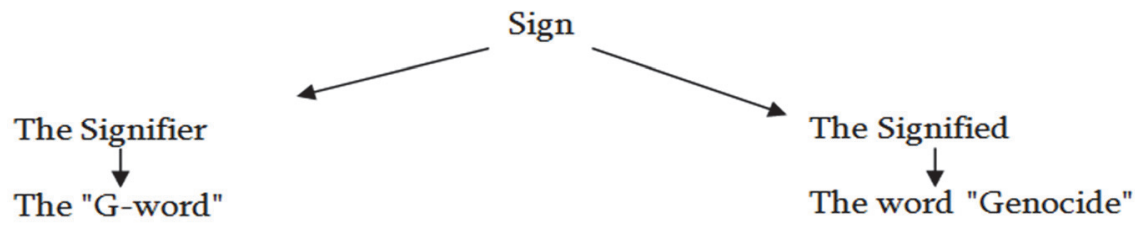


Thus, the primary interpretation can be actualized — if the 'G-word' will be substituted by the term 'genocide.' However, in the official discourses due to different reasons both of them are not acceptable. Thus, since the word 'genocide' is not mentioned, such primary denotative interpretation is failed, as it derived from the nonexpressed term. The scheme itself became more complicated: on the one hand, the neutral term 'Events of 1915' was used, while on the other hand, this expression is used as a new sign, a substitute for the implied term 'genocide'. The events of 1915 are described by such expressions as those that could be considered as characteristics of genocide.

The signified, what is denoted — the events of 1915 — are specified through the linguistic expression "the forced exile and mass killings of as many as 1.5 million Armenians during the last days of the Ottoman Empire" ". The latter acquires new semantics: it becomes the signified for the events that are usually defined by the term 'genocide', but this term is not used. Thus, the expression 'The events of 1915' in the Armenian Remembrance Day commemoratory statements with new semantics may be used to substitute the terms the former US Secretary of State Colin Powell named as 'indicators of genocide' ${ }^{12}$ (e.g. 'mass killing', 'atrocities', 'massacres' etc.). These terms, however, evade any direct reference to the implied term 'genocide', as it can be observed in the following: "the forced exile and mass killings of as many as 1.5 million Armenians during the last days of the Ottoman Empire". Similarly, the new semantics of the neutral expression 'The events of 1915 ' calls for further specification, therefore, it is substituted by more definite evaluative characteristics (in G. W. Bush statements: "one of the great tragedies in history", "a horrible tragedy", and, finally, referring to the Armenian naming, as "The great calamity"). It is not surprising then that there appear certain semantic dynamics related to both signifiers and signifieds. Signifying expressions are very close by their meaning to the term 'genocide', and the described events are "indicators of genocide":

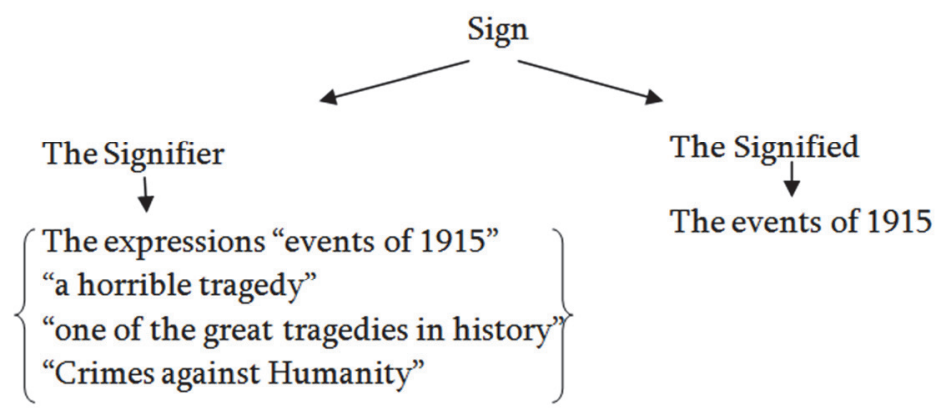

11 This expression with some non-relevant variations is used in all of G. Bush Statements, from 2001 till 2008. The Statements of American presidents are available on: http://www.armeniangenocide.org/current_category.4/affirmation_list.html (accessed 06.12.2018).

${ }^{12}$ Cf.: "Colin Powell, US secretary of state,... after visiting Sudan last week, he talked of "some indicators, but certainly not a full accounting of all the indicators that lead to a legal definition of genocide" - Jonathan Birchall. World agonises over definition of genocide as thousands die in Sudan - Financial Times, 06/07/2004. However, two month ago C. Powell changed his mind and calls Sudan killings genocide. — see: www.cnn.com/2004/WORLD/africa/09/09/sudan.powell//. This controversial situation is also described in: Scott 2005. 
The complex of these nominations can be considered as a hyper-sign, which is synonymous to the semantic structure of the term 'genocide'. The only matter is to simplify this complicated discourse construction by using the single proper term: as Obama wrote in his letter, 'Ambassador Evans "properly used the term 'genocide' to describe Turkey's slaughter of thousands of Armenians starting in 1915", and this can be represented as:

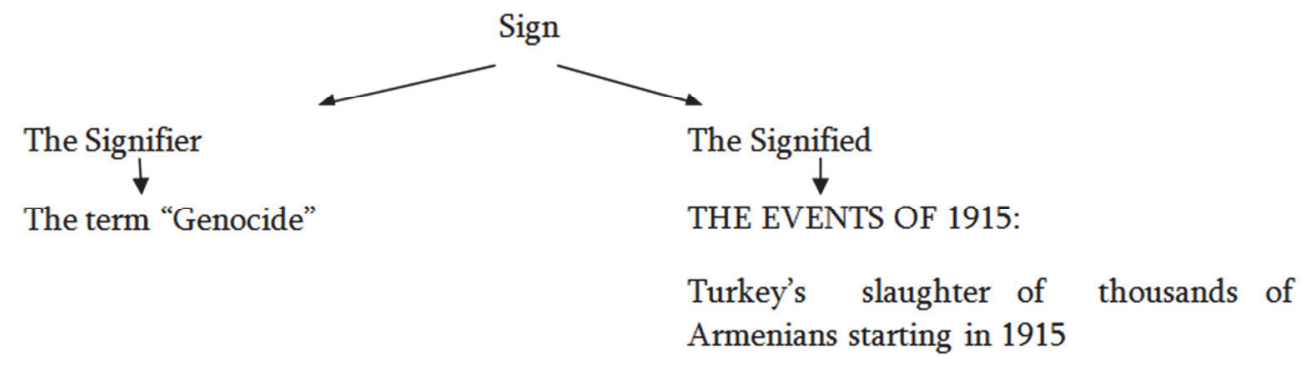

However, when already a president, Obama chose the other option: instead of the clear and direct denotation, he introduced different modes of more complicated connotative manipulations. In all of his Statements, he also used expressions which refer not to the events (primary referent), but the descriptions of these events (secondary referent). As a result, as he referred to the linguistic expressions describing events and not the events themselves, he creates a platform to avoid the usage of the word 'genocide'. This can be achieved in two ways. The first one is the traditional way of synonymic substitution for the "tabooed" G-word, i.e. using another word as a signifier for the same signified, as the previous presidents had done resorting to such periphrastic expressions as: "one of the great atrocities of the 20th century" (2009), "[...]in that dark moment of history", "1.5 million Armenians were massacred or marched to their death in the final days of the Ottoman Empire" (2010), "these terrible events" (2009, 2010), "the horrific events that took place ninety-six years ago" (2011), "one of the worst atrocities of the 20th century" $(2011,2012)$.

Meanwhile, he introduces also the new type of substitution based on intertextual reference. As we shall demonstrate below, he refers to texts where the same events were denoted through the term 'genocide'. Obama combines and develops both of them to create an impression that he expresses the same ideas as earlier and does not violate his promise "to speak truthfully about the Armenian genocide" but without uttering the word 'genocide'. Thus, Obama's statements formally do not violate the canonic discourse of his predecessors. The irresolvable ambiguity creates ground for ambivalent interpretation. It becomes the principal characteristic of Obama's discourse on the Armenian genocide.

Obama has introduced a new, intertextual pattern of reference: his text refers to another document where the addressee can find the "true" expression. The simplest way to prevent some possible allegation is the auto-quotation. On April 6, 2009, in Istanbul, president Obama was asked by Christy Parsons from Chicago Tribune:

As a U.S. senator, you stood with the Armenian-American community in calling for Turkey's acknowledgment of the Armenian genocide, and you also supported the pas- 
sage of the Armenian genocide resolution. You said, as President, you would recognize the genocide. And my question for you is, have you changed your view, and did you ask President Gul to recognize the genocide by name? ${ }^{13}$

The president's answer was:

Well, my views are on the record, and I have not changed views.

It was natural that the journalist would like to have a more definite answer, so she continued:

If I understand you correctly, your view hasn't changed, but you'll put in abeyance the issue of whether to use that word in the future?

This episode can explicate the dilemma between views which are on the record and which contain the proper naming and the usage (or non-usage) of the word 'genocide'. Maybe, the journalist's question presupposes the simplest solutions: instead of being asked about previous records, one can refer to them. Thus, very soon, on 23 April, 2009, in his first presidential statement on the occasion of the Armenian Commemoration day Obama had declared:

I have consistently stated my own view of what occurred in 1915, and my view of that history has not changed. My interest remains the achievement of a full, frank and just acknowledgment of the facts.

This sentence is repeated in all of his forthcoming Statements $(2010 ; 2011 ; 2012$; $2013 ; 2014 ; 2015 ; 2016)$. In this way, Obama reaffirms his stance, but without any clarification as to what exactly his view is. The implied reader has to know Obama's all previous statements ("the records") and reconstruct what this quotation means. Thus, only the informed addressee who has a collection of Obama's speeches and statements is able to recognize the implied meaning of his statement.

The aforementioned statement has two meanings. In its referential mode, it means that Obama did not change his view of what occurred in 1915; in its connotational mode, it presupposes that Obama confirms opinion that what occurred in 1915 is genocide.

However, Obama now did not articulate it, and, following the conversational logic, the third level of interpretation can be added: now Obama "put in abeyance the issue of whether to use that word".

The non-usage of the word presupposes some reasons for it, so this also has some meaning (Now the main interest is: the achievement of a full, frank and just acknowledgment of the facts $^{14}$ ). Paradoxically, in this multilevel construction, the primary sign (the term 'genocide') is substituted by a semiotic zero sign, i.e. by non-usage of a sign. The tabooed word is substituted not by some synonymic expression, but by reference

${ }^{13} \mathrm{https}$ //www.whitehouse.gov/the-press-office/joint-press-availability-with-president-obama-andpresident-gul-turkey (accessed 06.12.2018).

${ }^{14}$ Cf.: "Colin Powell said he 'was more interested in taking care of the people' than arguing over definitions" — op. cit., Financial Times, 06/07/2004. 
to previous utterances. The semiotic scheme of such avoidance can be represented as follows:

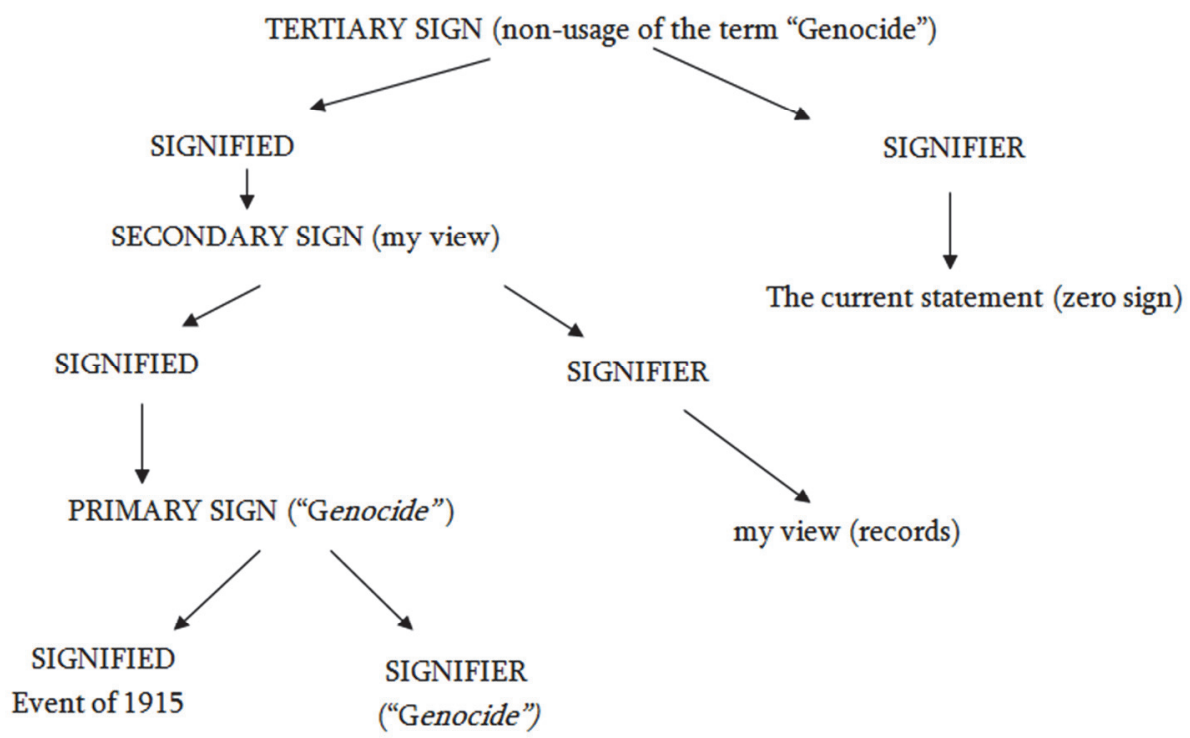

As one can see from this scheme, a sign of the previous level is served as signified for the complicated sign at the next level, and the proper meaning of the primary sign has been "buried" deeper with the emergence of a new level of interpretations. This situation reflects the new hierarchy of Obama's intentions: currently, "the achievement of a full, frank and just acknowledgment of the facts" is his highest priority. At the same time, the "buried" meaning of the term 'genocide' potentially can resurrect i.e. what is an acknowledgment of the facts if not a recognition of genocide? - as it was stated in Obama's letter to Condoleezza Rice ("the Armenian genocide in $1915<\ldots$..> is a widely documented fact"). Thus, the semiotic ladder can be transformed into a circle. At the last stage of interpretation, the complex sign can be considered as a reference to the initial un-uttered word 'genocide'. Even the non-usage of it can be treated as its meaningful manifestation by a zero-sign because any other sign could not substitute this. However, these semantic operations depend on interpretative strategy and contextualization, that is whether or not an addressee intends to take into account senator and candidate Obama's previous statements. As usual, a common addressee is not disposed to do it. However, at least theoretically, there is room for these semiotic exercises.

\section{5. 'MEDS YEGHERN’: THE INTERTEXTUAL STORY OF THE WORD}

The most remarkable and frequently mentioned novelty of Obama's discourse is the term 'Meds Yeghern'. Each of his statements contains reference to the Meds Yeghern:

The Meds Yeghern must live on in our memories, just as it lives on in the hearts of the Armenian people. <...> Nothing can bring back those who were lost in the Meds Yeghern (2009).

While nothing can bring back those who were killed in the Meds Yeghern (2010). 
Our hearts and prayers are with Armenians everywhere as we recall the horrors of the Meds Yeghern (2011).

Today, we commemorate the Meds Yeghern, one of the worst atrocities of the 20th century. On this solemn day of remembrance, we stand alongside all Armenians in recalling the darkness of the Meds Yeghern (2012).

Today we commemorate the Meds Yeghern and honor those who perished in one of the worst atrocities of the 20th century Today we stand with Armenians everywhere in recalling the horror of the Meds Yeghern (2013).

Today we commemorate the Meds Yeghern and honor those who perished in one of the worst atrocities of the 20th century. Today, our thoughts and prayers are with Armenians everywhere, as we recall the horror of the Meds Yeghern (2014).

This year we mark the centennial of the Meds Yeghern, the first mass atrocity of the 20th Century (2015).

Today we solemnly reflect on the first mass atrocity of the 20th century - the Armenian Meds Yeghern - when one and a half million Armenian people were deported, massacred, and marched to their deaths in the final days of the Ottoman empire. <..> Today we stand with the Armenian people throughout the world in recalling the horror of the Meds Yeghern and reaffirm our ongoing commitment to a democratic, peaceful, and prosperous Armenia (2016).

The unexplained expression 'Meds Yeghern' (transliteration of the Armenian name of the 1915 genocide, like the Shoa for the Jewish Holocaust) becomes the key word in Obama's discourse. This word can be evaluated as a symbolic representation of Obama's discourse, and it means 'everything and nothing'. For Armenians, this indicates full acceptance of their point of view and even their language, but for the rest of the world, it is only a meaningless sign.

Of course, Barack Obama was not the first to use this term, but he makes it the emblem of his attitude and innovation. What is more, Obama coined the new English words, as he converted this item into the English speech. Now this word is included in various online English dictionaries and even in the English-Turkish online dictionary ${ }^{15}$. However, as an English word, it has a very narrow scope of usage and appears mostly in Obama's statements on the Armenian genocide and in the commentary thereof. The Armenian word denoting the Armenian genocide characterizes Obama's discourse on the genocide. However, previous usages are also remarkable and may contribute to possible intertextual interpretations and misinterpretations.

Before Obama, President George Bush used this Armenian word, but he represented it in the translated version with some explanation on its connotations:

Today marks the anniversary of a horrible tragedy, the mass killings and forced exile of countless Armenians in the final days of the Ottoman Empire. Many Armenians refer to these appalling events as the "great calamity", reflecting a deep sorrow that continues to haunt them and their neighbors, the Turkish people (2003).

On Armenian Remembrance Day, we remember the forced exile and mass killings of as many as 1.5 million Armenians during the last days of the Ottoman Empire. This terrible event is what many Armenian people have come to call the "Great Calamity" (2005).

$15 \mathrm{https} / / /$ www.yourdictionary.com/meds-yeghern; https://ru.glosbe.com/en/ru/Meds\%20Yeghern; https://www.definitions.net/definition/MEDS\%20YEGHERN; http://tureng.com/en/turkish-english/ meds\%20yeghern (accessed 12.12.2018). 
As one can see, the new term 'Great Calamity' is introduced as a reference to the Armenians' usage, but not as his own. This is a quotation from the Armenian discourse incorporated within the official American text and it demonstrates that the administration is aware of the Armenian stance and in some (unspecified) respect expresses their solidarity with it. In Obama's case, the semiotic transformation is based on a metalinguistic operation - the primary Armenian sign Utho tintug — is transliterated (in contrast to Bush's translation) and becomes the signified for the newly coined English word 'Meds Yeghern':

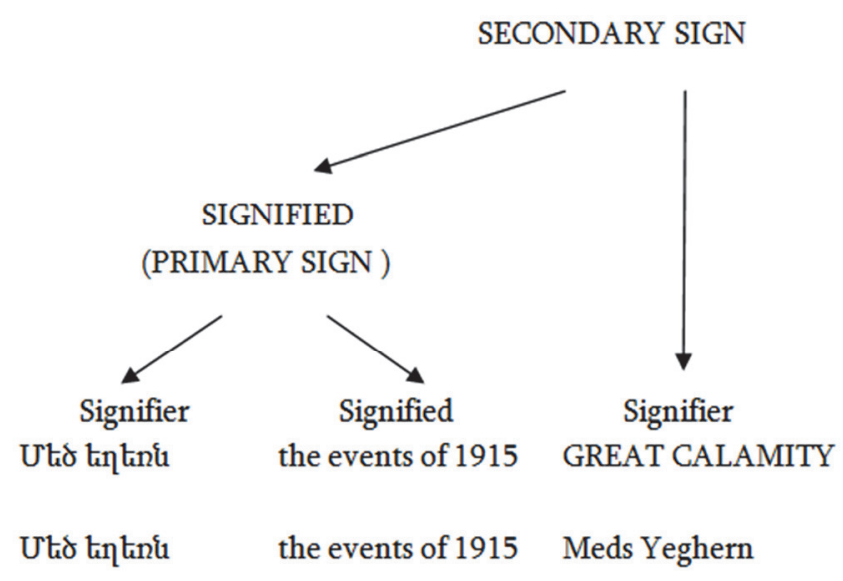

However, the proper representation of the Armenian point of view would be "a little" different: certainly, this terrible event is what many Armenian people have come to call the "Great Calamity" (Meds Yeghern, Uto tintnd), but Armenians use it in their language and their inner discourses: on all the other occasions, they refer to these events as 'the genocide' (ghquuuuunıpjnı\&, tsexaspanut'yun). So, as one can see, the Great Calamity can be considered as a literal translation of the polysemic 'Meds Yeghern' (we do not concentrate on other variants ${ }^{16}$ ), but it is somewhat problematic to use it as a correct translation concerning the events of 1915.

Pope John Paul II used such a bilateral model (inner, personal vs. outer, public) of the naming of the events of 1915 during his visit to Armenia ${ }^{17}$. On 26 Sep, 2001, in his speech given in Yerevan at the Genocide Memorial, Pope John Paul II read the following prayer in English:

Listen, O Lord, to the lament that rises from this place,

To the call of the dead from the depths of the Metz Yeghérn,

${ }^{16}$ See: Vartan Matiossian. When Dictionaries Are Left Unopened: How 'Medz Yeghern' Turned into Terminology of Denial. // Armenian weekly, November 27, 2012 (http://armenianweekly.com/ 2012/11/27/when-dictionaries-are-left-unopened-how-medz-yeghern-turned-into-terminology-ofdenial). In accordance of NOW (News on the Web) corpus, in the English texts there also the other translations: the Great Evil, The Great Crime, The great catastrophe.

17 Vartan Matiossian. The-birth-of-great-calamity Armenian weekly, October 25, 2012 http://www.armenianweekly.com/2012/10/25/the-birth-of-great-calamity-how-medz-yeghernwas-introduced-onto-the-world-stage/comment-page-1/\#comment-72225 (accessed 12.12.2018). 
The cry of innocent blood that pleads like the blood of Abel,

Like Rachel weeping for her children because they are no more ${ }^{18}$...

The next day, on 27 Sep, the Pope and the Catholicos of All Armenians Garegin II signed a joint declaration which addressed "the extermination of a million and a half Armenian Christians, in what is generally referred to as the first genocide of the Twentieth Century"19.

As one can see, Pope John Paul II used the untranslated "Meds Yeghern" in his communication with the Lord (the omniscient Divinity does not need any translation). Standing at that moment among Armenians but communicating with the world, the Pope chose the commonly used term 'genocide'. This dual nomination was a true representation of the Armenian stance. Perhaps not evident for a lay audience, the usage of 'Meds Yeghern' was however considered as an avoidance of the proper naming by journalists ${ }^{20}$.

However, the semantic and pragmatic ambiguity of the term 'Meds Yeghern' may create many possibilities for maneuvering between recognition and avoidance. Obama himself had become an actor of such word play. After the dismissal of Ambassador Evans, President Bush had to nominate a new ambassador to Armenia, and his nominee had to be confirmed by the Senate Foreign Relations Committee. It was a chance for revenge, and the Committee did not miss it. The main issue for discussion with the designated ambassadors to Armenia, Turkey, and Azerbaijan was the Armenian genocide. Some of the nominees were not confirmed. Democratic senators held up the confirmation of Amb. Richard Hoagland twice: he was in line with instructions of the administration and denied to address the events of 1915 as genocide ${ }^{21}$. The new nominee Marie Yovanovitch took lessons from that incident, and she looked more prepared and flexible. During Senate confirmation hearing, Senator Obama used strong language, he asked three questions, and each of them contained the word "genocide". The new nominee did not oppose to the senator's view, she agreed with him, but without uttering the prohibited term:

Obama: "How do you characterize the events surrounding the Armenian genocide?"

Yovanovitch: "...The United States recognizes these events as one of the greatest tragedies of the 20th century, the Medz Yeghern, or Great Calamity, as many Armenians refer to it".

${ }^{18}$ The full text see in:. https://w2.vatican.va/content/john-paul-ii/en/speeches/2001/september/ documents/hf_jp-ii_spe_20010926_prayer-yerevan.html (accessed 12.12.2018).

19 https://w2.vatican.va/content/john-paul-ii/en/speeches/2001/september/documents/hf_jp-ii_spe_ 20010927_decl-jp-ii-karekin-ii.html.

${ }^{20}$ Cf.: "The BBC rushed to report the same day of the prayer that, "The Pope has skirted controversy [with Turkey] on his visit to Armenia by avoiding the word 'genocide' in his prayers for those who died at the hands of Ottoman Turks... His use of the Armenian term, 'Metz Yeghern,' which means great calamity, to refer to the murders staved off the potential diplomatic storm which the word 'genocide' might have provoked from Turkey". The analyst Felix Corley repeated the equation "Metz Yeghern = big calamity", and stated that it is "the term the Armenians have used which has the same resonance as 'Shoah' does for Jews". "Pope Avoids Armenia Controversy", www.news.bbc.co.uk/ 2/hi/europe/1564257.stm; in: http://www.armenianweekly.com/2012/10/25/the-birth-of-great-calamityhow-medz-yeghern-was-introduced-onto-the-world-stage/comment-page-1/\#comment-72225 (accessed 12.12.2018).

${ }^{21}$ New U.S. Ambassador Arrives in Armenia, 18/09/2008, RFE/RL Armenia Report. http://www.azatutyun.am/a/1597391.html (accessed 12.12.2018). 
Obama: "If confirmed, what actions will you take to remember the victims of the Armenian genocide?"

Yovanovitch: "If confirmed, I will continue the tradition of participating in the official memorial event held in Yerevan every April. I will refer to this great historical catastrophe as the Medz Yeghern; the term often used within Armenia to refer to that dark chapter of history".

Obama: What steps is the State Department taking to encourage greater study and recognition of the Armenian genocide in Turkey?

Yovanovitch: The U.S. Embassy in Ankara is committed to working with the Government of Turkey on ways in which the atrocities of 1915 can be studied ${ }^{22}$.

Marie Yovanovitch was confirmed successfully, and she served as the Ambassador to Armenia during Obama's presidency. Ex-officio, she was obliged to participate in preparing and maybe, drafting the presidential addresses on the Armenian-American relations. There is no need to go into details to what degree the newly appointed ambassador then was assisting her previous interrogator, but the similarity between the abovecited dialogue and President Obama's statements on Meds Yeghern is evident. Answers received from Amb. Yovanovitch constituted their core semantics and pragmatics. In spite of that, the authorship is ascribed to Obama. However, there is no copyright in politics. Now the expression 'Meds Yeghern' has become the quasi-official euphemistic designation of the events of 1915, and it has been permanently used even by Obama's most eager rival, Donald Trump. Perhaps, this is one of the very rare cases of consensus between them: the wording of Trump's Statements is an exact copy of Obama's text ${ }^{23}$.

\section{OBAMA'S LAST WORD}

Obama's text was repeated every year with few insignificant modifications. Unsurprisingly, it lost its creative force and became a ritualized performance. The term 'Meds Yegern' became rather a new routine euphemism than a semantic novelty. However, the Centennial of the Meds Yeghern in 2015 was an extraordinary event, and the repetition of previous texts may have been regarded as inappropriate. Besides, there was strong political pressure on the President. It was argued that the Centennial is a proper occasion for a formal recognition of the genocide. Some experts had predicted that Obama would find the middle by uttering the word 'genocide' as a quotation from Reagan's statement on the Nazi Holocaust mentioned above (Amb. Rouben Shugarian, personal communication). It did not happen; Obama did not use this word even in the reported speech. Instead, Obama found new possibilities for non-uttering and at the same

${ }^{22}$ Question for the Record Submitted to Ambassador-Designate Marie L. Yovanovich by Senator Barack Obama, Senate Foreign Relations Committee - June 19-20, 2008, https://anca.org/ change/docs/Obama_Armenian_Genocide.pdf (accessed 12.12.2018).

${ }^{23}$ Compare: "This year we mark the centennial of the Meds Yeghern, the first mass atrocity of the 20th Century. Beginning in 1915, the Armenian people of the Ottoman Empire were deported, massacred, and marched to their deaths". (Obama 2015), with: "Today, we remember and honor the memory of those who suffered during the Meds Yeghern, one of the worst mass atrocities of the 20th century. Beginning in 1915, one and a half million Armenians were deported, massacred, or marched to their deaths in the final years of the Ottoman Empire". (Trump, 2017) https://am.usembassy.gov/remembrance-day/ (accessed 12.12.2018). 
time referring to the tabooed word. Inter-textual linkages, self-reference, non-correct quotation, context-dependent expressions, slips of the tongue are the poetic devices which constitute the implied semantics of the text issued on the occasion of the Centennial of the Meds Yeghern.

In contrast to the previously reviewed cases, the word 'genocide' is not used in the text of the Statement, but it is present in the texts to which the Statement refers. The key verbal signs of the text itself are not a replacement for an unsigned word, but they act as an equivalent of another text where this word is expressed explicitly. The principle itself was used by Obama earlier in the simplest form of auto-quotation ("I have consistently stated my own view of what occurred in 1915, and my view of that history has not changed"), but now it is presented in a form that looks more like Borges story than a political text $\mathrm{t}^{24}$. The source is not indicated, and an addressee should guess the non-indicated cause, using provided convoluted and even disorienting cues.

Most importantly, these are proper names which not only designate certain persons but also act as a reference to their views. Obama's Statement of 2015 for the first time contains proper names, and each of them is a mark referring to significant documents. These are Amb. Henry Morgenthau (the American ambassador to Turkey, who was the first to report the total extermination of Armenians); Raphael Lemkin who coined the term 'genocide' and was the main author of the Genocide Convention; Pope Francis who identified the events of 1915 as "the first genocide of the 20th century". All these references and names mentioned by Obama direct the addressee to the texts where the crimes of 1915 are identified as genocide.

At the same time, in contrast to his letter to Condoleezza Rice in 2006, Obama uses the periphrases which transformed the initial quotations. An implied super-reader (let us use this kernel notion from modern poetics ${ }^{25}$ ) has to reconstruct the right version. These deviances are used as a sign-message for a knowledgeable and experienced reader to go beyond the text to the proper sources and make the corrections. Finally, this superreader will realize that the appropriate version can be found in Obama's previous statements.

Thus, the first sentence This year we mark the centennial of the Meds Yeghern, the first mass atrocity of the $20^{\text {th }}$ Century is a result of the contamination of two acceptable expressions, creating a new rather strange one:

One of the worst atrocities of the 20th Century (Obama); The first genocide of the twentieth century (Popes John Paul II, Francis) $==>$ the first mass atrocity of the 20th Century.

${ }^{24}$ Cf.: "Menard's Don Quixote establishes and promotes revolutionary ideas about reading and writing. As the narrator notes in the final paragraph, "Menard has (perhaps unwittingly) enriched the slow and rudimentary art of reading by means of a new technique the technique of deliberate anachronism and fallacious attribution" (Following Menard's example, readers can interpret canonical texts in fascinating new ways by attributing them to authors who didn't actually write them". Patrick Kennedy. Jorge Luis Borges, "Pierre Menard, Author of the 'Quixote"'. Study Guide // Thought Co. https://www.thoughtco.com/pierre-menard-study-guide-2207796?print (accessed 12.12.2018).

${ }_{25}$ Super-reader (M. Riffaterre, 1966), implied reader (Wolfgang Iser 1974), model reader (Umberto Eco or informed reader (Stanley Fish 1980) - these terms designate a constructed person, not having any real existence (or even a structure inscribed or prescribed in the texts) who is only competent to made out an authentic meaning of a text and provides its "true" interpretation. 
It is not clear which event can be identified as the first mass atrocity, but the name of Pope Francis in the third paragraph will direct to Pope's correct wording (see below). The Pope's name will also retrieve the situation by introducing the term 'Meds Yeghern'. A similar situation happens with the interpretation of the second paragraph:

As the horrors of 1915 unfolded, U.S. Ambassador Henry Morgenthau, Sr. sounded the alarm inside the U.S. government and confronted Ottoman leaders. Because of efforts like his, the truth of the Meds Yeghern emerged and came to influence the later work of human rights champions like Raphael Lemkin, who helped bring about the first United Nations human rights treaty.

If one would like to know "the truth of the Meds Yeghern", one is directed to the authentic documents by Henry Morgenthau and the other U.S. officials, as this was done in the letter by Obama to Rice where the following reference was used as the confirmation of the Armenian genocide:

At the time of killings, it was U.S. State Department officials working in the Ottoman Empire who drew attention to the horrors describing the massacres as a "campaign of race extermination" (U.S. Ambassador to the Ottoman Empire from 1913-1916, Henry Morgenthau).

A similar inter-textual journey can be made starting from the mentioning of Raphael Lemkin, a lawyer who is internationally known as the author of the genocide Convention. At the same time, usually, The Universal Declaration of Human Rights is considered the first United Nations human rights treaty. The tricky thing is that the UN adopted the genocide Convention on 09 Dec, 1948, while the Declaration was adopted a day later (10 Dec, 1948). As in the previous case, the "true" version is also referred to in Obama's letter:

It was his study of the Turkish massacres of Armenians that motivated Raphael Lemkin to coin the word 'genocide' in 1941 and to press for the drafting and passage of the UN Genocide Convention in 1948.

As one can see, the second paragraph is an intentionally confused version of what was once explicitly written by Obama. In the case of George W. Bush, this probably would have been perceived as just a "Bushism" of confusing the Genocide Convention with the Universal Declaration of Rights. However, in Obama's case, there is a different principle; "Bushism" is incompatible with his image as an intellectual leader. An informed addressee should take this as a hint on which he can restore the "correct" text and thereby understand what the author wanted to say and $\mathrm{n}$ a certain respect indeed expressed, although without uttering.

The remaining paragraphs of the Statement of 2015 do not substantially differ as compared with Obama's previous statements, except the very remarkable instance in the fifth paragraph:

We welcome the expression of views by Pope Francis, Turkish and Armenian historians, and the many others who have sought to shed light on this dark chapter of history.

This unclear phrase refers to the opposite points of view expressed immediately before the 2015 Statement and can be explained through intertextual references. The first 
source is obvious - the aforementioned speech of Pope Francis. However, it is unclear what and when the Armenian and Turkish historians said and which of them Obama specifically had in mind. Most Turkish historians deny the fact of genocide, and the few of them who recognize it are outside Turkey (in Turkey this is considered as an insult to national dignity and is subject to criminal prosecution). In Obama's previous statements, the theme of recognition of the dark pages of history constantly resounds. However, none of them contains any mention of historians themselves. Probably Obama meant not real, but "intertextual" historians dwelling in the virtual space of the Turkish President Recep Erdogan.

Here also the principle of multilayered semantization creating uncertainty and ambiguity is enacted. Though welcoming the fact that Pope Francis was "expressing a point of view", Obama could not be unaware that the Pope's statement caused a violent reaction of the Turkish authorities and President Erdogan personally and, in its turn, of the European Parliament: Turkey recalled its ambassador, and Erdogan made a statement violating all diplomatic norms:

Whenever politicians, religious functionaries assume the duties of historians, then delirium comes out, not fact. Hereby, I want to repeat our call to establish a joint commission of historians and stress we are ready to open our archives. I want to warn the pope to not repeat this mistake and condemn him. His remarks display the appearance of a mentality different to that of a religious functionary. http://www.bbc.com/news/worldeurope-32309044 (accessed 12.12.2018).

Besides the invectives addressed to the pontiff, Erdogan repeated his favorite thesis that the events of 1915 are history, and therefore only historians must deal with it, for which it is necessary to create a joint commission of Armenian-Turkish historians. (Moreover, the conclusions to which these historians must come are clear for Erdogan: "I won't let historical events be brought out of their own course and turned into a campaign against our country and nation”).

Such offensive words to the Pope provoked a strong reaction. In particular, the European Parliament considered supplementing the upcoming resolution with another clause in which it expressed its solidarity with Francis:

Commends the message delivered by His Holiness Pope Francis honouring the centenary of the Armenian genocide on 12 April in a spirit of peace and reconciliation.

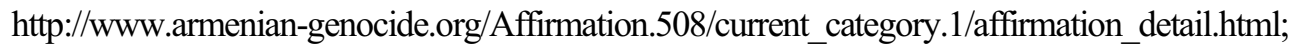
(accessed 12.12.2018).

As we can see, Obama, following the European Parliament, agrees with Francis and welcomes his point of view, but at the same time considers it necessary to "welcome" the point of view of "Armenian and Turkish historians", existing only as a long-lasting project of the Turkish president. This collocation of different stances without any specification also creates the effect of poetic semantics. Different, even opposing interpretations can be suggested as to how the "truth about Meds Yeghern" should be understood.

Summarizing our observations on Obama's 2015 Statement, we see that all innovations are intertextual references. The implied meanings constituted something like 
a coherent story, but without its textual manifestation. This post-modernist discourse takes into consideration not only what was said but also deduced. Addressees are authorized to reconstruct allusions and explicate intertextual meanings and messages associated with the main text. Thus, Obama's Statement of 2015 can be compared with a hypertext - it contains a proper, verbally expressed text, implied texts, a set of precedential documents and intertextual linkages between all these entities. Is there a "true" text? There is room for different approaches.

All these different but interconnected texts are nevertheless considered being in aggregate; they form a kind of additional message with the main verbal text. Although each of them simultaneously refers to several sources and may allow different interpretations, they all converge at one point and turn out to be an intertextual metonymic replacement of the word 'genocide'. Considered as a complex, they appear as a semantic structure, united around this principal meaning and referring to the texts that explicate it.

Question arises as to who the recipient of this message is. Indeed, the audience to which the text is oriented is not able to restore this whole complex; therefore the intertext created by Obama is apparent only to himself. He is supposed to be this "super-reader" who knows all contexts and intertexts. "Common readers" may perform a role that is intended for them by the super-reader i.e. to accommodate their understanding of the text with their expectations and be satisfied with the fact that understanding coincides with expectations. However, in this case, the tabooed word 'genocide' reveals the "author's" controversy; who implicitly, through intertextual links, expresses what he avoids to express explicitly in the text.

The hermeneutic approach can be also legitimized. What is more, it appears to be an adequate challenge-response for this type of communication. An interpreter is authorized to reconstruct allusions and explicate inter-textual meanings and messages, which are implicitly incorporated within the text, especially if the author slots distinctive marks and hints in his text for finding the "true" expression. The author himself has nothing to add: in 2016, in the year of his term expiry, Obama issued his last statement; it almost literally repeated the previous one. Obama also exhausted all the means of his non-doing things with the Word - or doing things by non-using it.

\section{CONCLUSIONS}

Summing up our observations of Obama's statements, we can conclude that almost all his innovations and semantic strategies are based on intertextual references. Although these references relate to multiple sources and can be comprehended differently, they all converge at one point and are the intertextual metonymical substitute for the word 'genocide'. Considered as a single complex, they act as a semantic structure united around this core meaning and referring to texts explicating and naming them. Together, they form an additional message concerning the issued statements.

As opposed to Clinton and Bush's traditional rhetoric, Obama's post-modernist discourse takes into consideration not only what is expressed but more what is or might be implied. An interpreter is authorized to reconstruct allusions and explicate intertextual meanings and messages, which are implicitly incorporated in the text. This amalgam 
of the lexically articulated and con- (inter-)textually implied meanings provides an opportunity to be in line with the statements of his predecessors and avoid keeping his promises, at the same time declaring the opposite and referring to his previous records.

The hypertext created by Obama is based on its intertextual linkages. It is understandable only to himself as that "super-reader" who knows all contexts, subtexts, and references. However, all these sophisticated linguistic strategies are based on a primitive taboo. The taboo is a distorted form of semiosis when the link between the signifier and the signified is considered as an absolute. It is presumed that non-usage of the signifier affects the signified (existence/non-existence of some state of affairs). Taboos can be overcome only if one abandons the borders of political mythology. If interpreted in accordance with post-modernist principles, the text is not subject to conventional procedures of verification or falsification, so another hermeneutic approach appears to be the adequate instrument for its interpretation and the resulting deconstruction. Such an interpretive approach is consistent with the strategy used by Barack Obama for semantic and pragmatic structuring of his messages, so there are sufficient grounds to consider Obama's statements in entirety with these texts. Within this approach, the addressee of his messages is sanctioned to interpret them as recognition of the Armenian genocide. Ironically, this reminds one of Friedrich Schleiermacher's basic principle of hermeneutic interpretation: a possibility of understanding the author as well or even better than he understands himself.

(C) Suren T. Zolyan, 2019

\section{REFERENCES}

Cirillo, David. The Taboo of the Armenian Genocide. Part 2. The American Avoidance // IFRI = Institut Français des Relations Internationales. Reperes sur le Turqule. № 15, June 29, 2016.

Eco U. The Role of the Reader: Explorations in the Semiotics of Texts. Bloomington, Indiana University Press, 1984.

Fish, Stanley. Is There a Text in This Class? The Authority of Interpretive Communities. Cambridge, Mass.: Harvard University Press, 1980.

Gutman D. Ottoman Historiography and the End of the Genocide Taboo: Writing the Armenian Genocide into Late Ottoman History. Journal of the Ottoman and Turkish Studies Association. 2015, 2. 167-183.

Hjelmslev, Louis. 1961 [1943]. Prolegomena to a theory of language. Madison, WI: University of Wisconsin Press.

Iser, Wolfgang ([1972] 1974). The Implied Reader: Patterns of Communication in Prose Fiction from Bunyan to Beckett. Baltimore: Johns Hopkins UP.

Lemkin, Raphael. On the Armenian Genocide. Charny I.W.; Wiesenthal S., Tutu D. (Eds). Encyclopedia on Genocide, ABC-CLIO, 1999, 79.

Riffaterre M. Describing Poetic Structures: Two Approaches to Baudelaire's 'Les Chats'. Yale French Studies 36-37 (1966): 200-242.

Scott Straus. Darfur and the Genocide Debate. Foreign affairs. January/February 2005, 123-133.

Waal de, Thomas. The G-Word. The Armenian Massacre and the Politics of Genocide. Foreign affairs (Council on Foreign Relations). January/February 2015 Issue 94. 1-25; https://www.foreignaffairs.com/articles/united-states/g-word (accessed 03/12/2018). 
Wilson Woodrow - 66th Congress 2nd Session House of Representatives Document No. 791. Mandate For Armenia Message from the President of the United States, requesting that the Congress grant the executive power to accept for the United States a mandate for Armenia May 24, 1920. http://www.armenian-enocide.org/Affirmation.64/current_category.4/affirmation_detail.html (accessed 03/12/2018).

Zolyan S.T. The American Presidents on the Armenian Genocide. The Semantics and Pragmatics of the Evasionist Discourse. Yerevan, "Limush" Publishing, 2015. (In Armenian).

\section{FINANCE AND ACKNOWLEGMENTS}

The research is funded by the Russian Science Foundation, project № 18-18-00442 "Mechanisms of meaning production and textualization in social narrative and performative discourses and practices", at the Im. Kant Baltic Federal University, Kaliningrad, Russia.

\section{Article history:}

Received: 09 September 2018

Revised: 28 October 2018

Accepted: 18 November 2018

\section{История статьи:}

Дата поступления в редакцию: 09 сентября 2018

Дата принятия к печати: 18 ноября 2018

\section{For citation:}

Zolyan, Suren (2019). How Not To Do Things with the Word: Barack Obama on the Armenian Genocide. Russian Journal of Linguistics, 23 (1), 62 - 82. doi: 10.22363/2312-9182-2019-23-1-62-82.

\section{Для цитирования:}

Zolyan, Suren (2019). How Not To Do Things with the Word: Barack Obama on the Armenian Genocide // Вестник Российского университета дружбы народов. Серия: Лингвистика = Russian Journal of Linguistics. 2019. T. 23. No 1. C. 62-82. doi: 10.22363/2312-9182-2019-23-1-62-82.

\section{Bionote:}

SUREN ZOLYAN, Ph.D. (Advanced Doctorate), Professor, Immanuel Kant Baltic Federal University (Russia); Leading Researcher, Institute of Philosophy, Sociology and Law, National Academy of Sciences of Armenia.

Contact information: e-mail: surenzolyan@gmail.com

\section{Сведения об авторе:}

СУРЕН ТИГРАНОВИЧ ЗОЛЯН, доктор филологических наук, профессор, Балтийский федеральный университет им. И. Канта, Россия; ведущий научный сотрудник, Институт философии, социологии и права Национальной академии наук Армении.

Контактная информация: e-mail: surenzolyan@gmail.com 